\title{
Corporate Institutions in a Weakened Welfare State: A Rawlsian Perspective
}

\author{
Sandrine Blanc \\ INSEEC Business School
}

Ismael Al-Amoudi

University of Reading

\begin{abstract}
This paper re-examines the import of Rawls's theory of justice for private sector institutions in the face of the decline of the welfare state. The argument is based on a Rawlsian conception of justice as the establishment of a basic structure of society that guarantees a fair distribution of primary goods. We propose that the decline of the welfare state witnessed in Western countries over the past forty years prompts a reassessment of the boundaries of the basic structure in order to include additional corporate institutions. A discussion centered on the primary good of self-respect, but extensible to power and prerogatives as well as income and wealth, examines how the legislator should intervene in private sector institutions to counterbalance any unfairness that results from the decline of the welfare state.
\end{abstract}

KEY WORDS: basic structure, corporate democracy, justice, Rawls, self-respect, welfare state

\section{INTRODUCTION}

$\mathrm{T}$ HIS PAPER RE-EXAMINES RAWLS'S THEORY OF JUSTICE, particularly its import for private sector institutions ${ }^{1}$ in the face of the decline of the welfare state (WS) over the past forty years or so. This question is important for two reasons, the first being that the philosophical status of corporate institutions (CIs) is still a matter of debate among political philosophers and business ethicists. The stakes of this debate are high: if CIs belong to the basic structure of society (BSS), then they must satisfy Rawls's principles of justice, first enunciated in his Theory of Justice (TJ). The second reason Rawls's theory of justice is important for private sector institutions is that if the question of the inclusion or exclusion of an institution from the BSS depends in part on empirical considerations, as argued below, then we must also consider the remarkable historical changes that distinguish our current societies from the society within which Rawls wrote TJ. In particular, we argue that the decline of the WS constitutes a development so significant that it requires reassessment of the boundaries of the BSS and the status of a number of key private sector institutions, such as those affecting corporate democracy ${ }^{2}$ and opportunities for meaningful work for the least favored. 
We organize our demonstration into five steps. First, we offer a brief historical overview of the contrasting evolutions of three WS models: social democratic, liberal, and corporatist. While the trajectory of change in the WS may differ across these models, overall our assessment points towards a clear decline in the WS that has a bearing on the ability of the least well-off to access the primary goods necessary for their own life projects. Second, we offer a refresher of Rawls's theory of justice that highlights the concepts and ideas particularly central to our argument. Third, we discuss political philosophy's recent contributions to normative literature on business and management. While we welcome interesting debates regarding the philosophical status of many CIs, we also note that no one has examined the potential implications of the decline of the WS. This is connected to the question of why Rawls seems to exclude CIs from the BSS and, more generally, whether recent transformations in the economic and political environments in which corporations function prompt a reassessment of CIs' philosophical status. We argue that setting the boundaries of the BSS and assessing the status of CIs cannot be decided entirely a priori but must also be informed by empirical considerations relative to each society's political, social, and economic context. In this light, the decline of the WS constitutes a significant contextual transformation affecting the systemic distribution of primary goods and therefore prompts a reassessment of the BSS's boundaries.

The fourth section builds on the previous three and expands our argument for one primary good: the social bases of self-respect. We show how the withdrawal of the WS jeopardizes access to this good for the least favored; further, how this can be addressed by liberal egalitarianism through changes to the philosophical status of some CIs and consequent policies. The fifth, final, section examines the choices between more democratic CIs and a restoration of the WS, the applicability of our proposals in a globalized world, and the extension of our reasoning to other primary goods.

\section{THE DECLINE OF THE WELFARE STATE IN CONTEMPORARY HISTORY}

\subsection{What Is the Welfare State?}

Although the WS is not a predominant topic in contemporary business ethics literature, Rawls's interest, as well as that of many other political philosophers, in the WS's normative justifications should not be surprising. At the time of Rawls's writings, the WS was a dominant political form in Western democracies. Indeed, Amy Gutmann wrote in the eighties that "every modern industrial state is a welfare state" (Gutmann 1988: 3).

According to Esping-Andersen (1990: 18-19), "WS" refers to states taking "responsibility for securing some basic modicum of welfare for [their] citizens" in an attempt to mitigate the effects of natural and social contingencies on the individual's life chances. Contemporary WSs are the product of a long history. Since the eighteenth century, the development of the state and its welfare institutions has been closely connected with an expansion of the protection of individual rights and liberties (Rosanvallon 1981, Stedman Jones 2005). WSs developed more rapidly in the nineteenth century (as a response to the negative social effects of industrializa- 
tion), and more so during the thirty years or so following World War II, resulting in a "fantastic pace of growth . . . during the 1960s and 1970s" (Esping-Andersen 1990: 1). In the United States (US), for instance, "federal spending on welfare increased from 8.2 to 18.7 per cent of the [gross national product] GNP between 1950 and 1980" (Gutmann 1988: 3).

Notable variations in the WS existed between countries, reflecting different approaches toward the extent of the benefits and the contingencies upon which access to these benefits were determined. Esping-Andersen famously distinguishes between three WS regimes: social democratic, corporatist, and liberal (EspingAndersen 1990: 26-27). At their height, Scandinavian social democratic WSs were service intensive, comprehensive with regard to the services offered, and universal in terms of coverage. They were also "massively redistributive" as a result of their universal coverage, high income replacement rates, and liberal qualifying conditions for benefits (Stephens 1996: 36-37). Overall, they have been characterized as "decommodifying" because the basis for entitlements was pure citizenship, rather than citizen inclusion in the labor market (Stephens 1996: 36). One important consequence is that, under this type of WS, "individuals [would] suffer relatively small losses of income from exiting paid work temporarily or permanently" (Stephens 1996: 36). In our view, the Scandinavian WS model comes closest to securing the Rawlsian ideal of cooperation on an equal footing.

The continental (corporatist) model differs in notable ways from the social democratic model. Influenced by Imperial Germany and its original purpose of perpetuating a set social order rather than decommodifying labor, it is characterized by a social insurance system organized under the auspices of the state. In practical terms, corporatist social insurance determines entitlements based on professional activity, consequently mirroring existing socio-economic statuses rather than redistributing resources and wealth. In Catholic southern European countries where state intervention was assumed to be subsidiary to family solidarity, the model emphasized generous cash transfers rather than public care services (Esping-Andersen 1996c). Some cautious universalism was introduced during the post-war era, however, accompanied by a shift towards calculating benefits from contribution- to earningsbased benefits (Esping-Andersen 1996c: 69).

Finally, the US, Canada, and Australia typify the liberal WS, which differs from both other WS models in that the WS is subordinate to markets as a purveyor of welfare. The liberal WS therefore tends to provide limited means-tested social benefits or modest universal transfers. As a result, it produces a stratified society with a "relative equality of poverty among state-welfare recipients, [and] marketdifferentiated welfare among the majorities" (Esping-Andersen 1990: 26-27).

\subsection{The Welfare State's Declining Trajectories in Western Countries}

WSs have been in crisis and decline since the mid-1970s (Esping-Andersen 1996b; Ferguson, Lavalette, and Mooney 2002; Fleurbaey 2006a; Rosanvallon 1981). This crisis is attributable to both the (endogenous) questioning of the WS's legitimacy and (exogenous) financial constraints. WSs have been blamed for impeding rather than 
fostering individuals' self-esteem (Gutmann 1988) and for consequently undermining political participation (Walzer 1988). Their bureaucratic procedures have been criticized for hampering welfare recipients' self-determination (Habermas 2005). In more practical terms, welfare policies have also been criticized for reducing recipients' incentives to work and save, and for consisting of out-dated programs addressing "a past social order" characterized by a long-gone, homogenous industrial working class (Esping-Andersen 1996a: 9).

In addition to these criticisms relative to their purposes and methods, WSs are also facing increasing financial difficulties due to recent economic and social developments. Aging populations burden health and retirement budgets while restricting public income. More critically, the economic conditions that happily combined growth and employment with egalitarian social policies during the post-war era no longer apply: from the 1970s onwards, the so-called "Keynesian consensus" has been replaced by a new trade-off between employment and egalitarianism (Esping-Andersen 1996a: 3). In today's globalized economy, nation states compete for investment and workforce, which in turn strictly limits the scope of possible tax policies and the consequent funding available for social transfers (Esping-Andersen 1996b). Likewise, Rosanvallon (1981) has pointed to the contradictions inherent in a situation that combines increasing welfare demand with a globalized production system that increases constraints on states' abilities to raise taxes to meet these needs.

The various regimes of WS have adapted differently to changing economic conditions. The Scandinavian WS, the success of which relied upon low unemployment and high labor force participation (Stephens 1996: 38) by combining social equality with economic efficiency (Stephens 1996: 32), was affected by the increased levels of unemployment prevalent from the 1970s onwards. The Scandinavian regime responded by "shifting welfare state resources from passive income maintenance to employment and family promotion" (Esping-Andersen 1996a: 25), thereby triggering increased inequalities. Even Sweden emphasized contribution-based entitlements (rather than defined benefits) and workfare policies (Esping-Andersen 1996a: 14). Although financial cuts occurred, the most significant evolution of Scandinavian WSs was arguably the shift of purpose, as the decommodification of labor gave way to workfare.

The European corporatist model, which assumed full-time careers by men (EspingAndersen 1996c: 76), also reacted to higher unemployment in ways that would undermine the least advantaged in the long term. The policy responses in continental Europe entailed labor-supply reduction through the "early retirement of male workers and discouragement of female participation, often combined with hours reduction" (Esping-Andersen 1996c: 77), rather than scaling back or reforming social security. This triggered an increase in social expenditure at levels difficult to sustain in the long run. For citizens, receiving WS benefits was moreover reinterpreted as exclusion from the labor market rather than as an exercise of personal choice.

The market-oriented liberal WS adapted to the post-OPEC era in another way. Markets had succeeded in providing North American workers with "enviable levels of economic well-being during the 'Golden Age' of postwar expansion" in spite of modest social welfare programs (Myles 1996); however, from the 1970s 
onwards, employment was sustained at the cost of widening wage differentials and expanding the ranks of the working poor. As highlighted by Myles, the low-wage/ high-employment model challenged the liberal WS, as low-wage workers would both increase demands for social transfers and have a limited capacity to contribute to their funding through taxes. Some states, such as Australia and Canada, reacted to this challenge with a combination of service liberalization and increased selectivity, as well as targeting, for benefits.

Overall, all three forms of WS moved towards freezing or eroding the number or amount of welfare benefits (Esping-Andersen 1996a: 24) or changed the conditions for accessing benefits, linking access to benefits increasingly to some former contribution in, or some willingness to contribute to, the work sphere.

What are the philosophical implications, if any, of the WS's decline and labor commodification for justice as fairness? The next section prepares the ground for this question by offering a refresher on Rawls's main ideas and concepts, and by examining the status of the WS in Rawls's realistic utopias.

\section{RAWLS'S THEORY OF JUSTICE: A REFRESHER}

\subsection{The Fair Distribution of Primary Goods}

Rawls (1971, 1993, 1999b, 2001) considers the conditions for a fair distribution of basic liberties and socio-economic advantages in a society of free and equal people; these are the conditions that the principles of justice must express. According to Rawls, these principles are those that representatives of individuals in a situation of social cooperation would adopt if they were to deliberate behind a veil of ignorancethat is, without information as to the individual's capacities, conception of the good, rational plan of life, and social position. Rawls then presents the two principles of justice that would be adopted in the "original position." The first principle requires the implementation of a fully adequate scheme of equal liberties that is compatible with the same scheme for all. The second principle sets out two sub-requirements for acceptable inequalities: i) social positions must be equally accessible to those endowed with similar talent and motivation (fair equality of opportunity); and ii) inequalities must be to the greatest benefit of the least advantaged members of society (difference principle) (Rawls 2001: 42).

Rawls then specifies the nature of the distribuendum, the distribution of which must be evaluated using the above principles of justice. Neither well-being nor happiness is considered a suitable distribuendum. Instead, Rawls suggests that social justice should consider the expectations of primary social goods attached to social positions. Primary goods are defined as goods that are useful independently of the individual's life plans and that any rational person should therefore desire. The five categories of primary social goods follow: i) basic rights and liberties; ii) freedom of movement and free choice of occupation; iii) powers and prerogatives; iv) income and wealth; and v) the social bases of self-respect (Rawls 2001: 58-59). To determine the fairness of a society, one must assess whether the allocation of primary goods among social positions conforms to the aforementioned principles of justice. The first principle is used for the evaluation of the fairness of a given distribution of 
rights and freedoms. The second principle (equal opportunities and the difference principle) offers a criterion for assessing the fairness of the distribution of powers and prerogatives, and income and wealth. The distribution of the social bases of self-respect is debated among Rawlsian scholars. ${ }^{3}$ They agree, however, that for the social bases of self-respect, as for other primary goods, fairness is guaranteed by some combination of the two principles of justice, to which Moriarty (2009) adds the opportunity for meaningful work. ${ }^{4}$

\subsection{The Basic Structure of Society as the Subject of Justice}

As Child and Marcoux (1999) and Phillips and Margolis (1999) remind us, Rawls is clear that his principles of justice are not meant to constrain the form of every institution and organization. Their domain of influence is restricted to the basic structure of society that associates primary goods with social positions. This BSS is defined as the "major social institutions [that] distribute fundamental rights and duties and determine the division of advantages from social cooperation" (Rawls 1971: 7).

The rationale for distinguishing the institutions of the BSS from all other institutions can be understood in light of Rawls's overall project. Society's most important institutions are those that a citizen cannot avoid unless s/he emigrates. A society's political constitution and its basic socio-economic structure are particularly salient examples. Citizens are autonomous vis-à-vis these institutions if the latter are structured according to principles stemming from "reflective thought and reasoned judgement" (Rawls 2005: 222), that is, principles that can be justified and appropriated through citizens' autonomous reasoning.

In the section of $T J$ dedicated to institutions, Rawls specifies the nature and content of the BSS: "by major institutions, [he] understand[s] the political constitution and the principal economic and social arrangements" (Rawls 1971: 7). The BSS therefore comprises two distinct parts, each dedicated to the realization of one of the principles of justice. The first part consists of the political constitution, the purpose of which is to establish a fully adequate scheme of basic liberties for all. The second part is dealt with by the legislature that defines and regulates the most important socio-economic institutions. On the one hand, these include the economic system of production and exchange of goods and its rules and regulations (for example, macroeconomic policies) and, on the other, the social system of taxation and redistribution that is regulated by the WS. ${ }^{5}$

Furthermore, since the legislature should only intervene in the BSS, it follows that the principles of justice offer quite some leeway for the actions of individuals and groups of individuals. They are not meant to guide the actions of individuals who remain free to act and undertake projects as they wish within society's background institutions, nor do the principles of justice define the fair distribution of privileges within private voluntary organizations, such as firms. The rules that apply to transactions and agreements between individuals and associations are those of private law. Legislation concerning contracts is an example of such laws that are "framed to leave individuals and associations free to act effectively in pursuit of their ends and without excessive constraints" (Rawls 2005: 268). 
Finally, Rawls's stance on corporations is loose: he notoriously considers the ownership of the means of production as belonging to the BSS (Rawls 1999b: 6), and he hints that corporate governance might also belong to it (Rawls 2001: 178); yet he largely treats corporations as private voluntary associations, as he does universities (Rawls 2001: 10, 164). It might be tempting to infer from this synopsis of Rawls's political philosophy that CIs fall primarily under the purview of private law. We argue below, however, that while such an inference is broadly correct in the context of a healthy WS, it is incorrect in the context of a declining WS.

\subsection{Rawls's Realistic Utopias: A Strong Welfare State and Overlooked Corporate Institutions}

Once the principles of justice and their subject are specified, Rawls considers models of socio-economic organization that may accommodate them. These models are ideal types of fair societies, as opposed to actual regimes. Two of them appear prima facie compatible with the principles of justice: market socialism (which combines market mechanisms of exchange with the public ownership of the means of production) and the model of a property-owning democracy (POD), for which Rawls indicates a personal preference. ${ }^{6}$ The expression "POD" is potentially misleading because of its libertarian tones, yet Rawls is clear that a POD must involve a powerful WS and favor the dispersal of capital within a production system based on the private ownership of the means of production. Adding to the confusion, Rawls also distances the POD from the model he calls, perhaps misleadingly, welfare-state capitalism (Rawls 2001: 136). It is crucial for our argument to note that Rawls's misgivings about welfare-state capitalism are prompted by its insufficient, rather than excessive, WS.

In a POD, policies of redistribution and limitations on the accumulation of capital ensure compliance with the second principle (i.e., social positions must be equally accessible to those endowed with similar talent and motivation, and inequalities must be to the greatest benefit of the least advantaged members of society). Redistribution modifies the allocation of income resulting from labor market mechanisms. Moreover, policies aimed at limiting the accumulation of capital—especially inheritance tax and progressive income tax-lead to a more egalitarian distribution of both capital and return on capital, which improves the situation of the least advantaged citizens. Thus, the two combined measures guarantee that the outcome will be consistent with the difference principle. Moreover, the resulting smoothing out of inequalities secures the conditions for fair equality of opportunities. Indeed, Rawls remarks that the development and expression of natural talents are strongly correlated with the initial social and familial circumstances that people experience. The smoothing out of these social conditions, combined with a public system of education, moves closer to offering similar prospects for equally talented and motivated individuals. Finally, the leveling down of inequalities also contributes toward ensuring the fair value of equal political liberties, requiring a fair opportunity for all to hold public office and influence election outcomes (Rawls 2001).

In contrast, the distributive role of the state in welfare-state capitalism does not conform to the demands of justice because it barely allows for the survival of the 
weakest and permits the private accumulation of land and capital. This, in turn, results in significant inequalities that undermine both the relevance of formal equal political liberties and the equality of opportunities expected from a well-ordered society. Welfare-state capitalism also ignores the difference principle since returns on capital are highly unequal and redistribution is limited to those who would not otherwise be able to support themselves (Rawls 2001: 139-40).

Overall, Rawls mainly focuses on questions relative to the WS while leaving aside questions relative to CIs. Worker-managed firms are at most mentioned as a topic for further enquiry (Rawls 2001: 178). Moreover, Rawls does not examine the potential implications of the absence or decline of the WS on the status of CIs. Below we outline recent political philosophy discussions about CIs and address whether Rawls's ignored CIs as a necessary ahistorical implication of the BSS's definition, or because he assumed a strong WS.

\section{FROM BUSINESS ETHICS TO POLITICAL PHILOSOPHY: CORPORATE INSTITUTIONS AND THE DECLINE OF THE WELFARE STATE}

\subsection{Political Philosophers'Surging Interest in Corporate Institutions}

Heath, Moriarty, and Norman (2010: 49) remark that "with very few exceptions, the question of the design and justification of private-sector institutions and regulations-and the implications for individuals within these institutions-has not attracted the attention of political philosophers." The authors temper this observation by pointing to exceptions in the domain of healthcare in the US. We agree with their assessment that until the end of the 1990s, business had been the obvious omission from political philosophy, and that, even today, much important work remains to be done. We note, however, political philosophers' (partial and incomplete) resurgence of interest in the world of business in general and into CIs in particular over the past decade or so.

As Heath, Moriarty, and Norman correctly highlight, the main contributions from political philosophy for business ethics come from authors sympathetic to Rawls, such as Cohen (1989b), Freeman (2007), Hsieh (2004, 2005), Moriarty (2005, 2009) and O'Neill (2008, 2009), to whom we would add Hussain $(2009,2012)$ and European authors such as Fleurbaey (2006a, 2006b). Recent contributions from political philosophy also include papers written from a libertarian perspective (Boatright 2004, 2006, 2010; Machan and Chesher 2002), as well as contributions from Marxist (Cohen 2008), and even radical democratic (Edward and Willmott 2008), perspectives.

While both business ethics and political philosophy examine normative questions, they do so from differing perspectives. Clearly, the distinction between the fields will vary slightly from one author to the next; generally, however, ethics is typically concerned with the (right) actions of individuals, whereas political philosophy is typically concerned with the formulation of (just) laws for society. This holds for Rawls's perspective on the difference between ethics and political philosophy: ethics is the study of criteria and practices constitutive of a good life, whereas political philosophy is the study of key institutions of society that allow each individual to 
lead a life that is good according to her own criteria (as long as these criteria do not impede the projects of others). A crucial implication is that political philosophy proposes rules that can and must be enforced by the state. It follows that Rawlsian political philosophy has little to do with individuals' supererogatory actions and associations' voluntary codes of conduct. We are therefore in complete agreement with Heath, Moriarty, and Norman's suggestion that Rawls's principles of justice are not meant to be applicable to each and every institution, but, rather, only to those that form part of the BSS (Heath, Moriarty, and Norman 2010: 432). Heath, Moriarty, and Norman also rightly remark that, as a result, authors applying Rawlsian theories to business studies have followed two strategies (2010: 431-33): they either applied the principles of justice to all interactions (for example, Cohen 2008); or they challenged the exclusion of corporations from the BSS.

Our argument is closest to the second strategy and addresses three questions. The first is the question of why Rawls himself repeatedly suggested that private firms should not be included in the BSS (Rawls 2001: 10). As we shall see, the reasons for Rawls's choice beg clarification on the (second) question: Which criterion should a Rawlsian use to distinguish entities belonging, and not belonging, to the BSS? The third question entails an examination of significant historical (and therefore empirical) changes that may determine whether certain CIs should be included in, or excluded from, the BSS. We attempt to respond to these three questions in the remainder of this section.

\subsection{Corporate Institutions in the Works of Rawls: A Voluntary Omission?}

Two distinct factors may account for Rawls's general lack of consideration for the types of corporate codes, practices, and decisions that should be regulated in a well-ordered society. First, Rawls's omission could be a matter of principle: CIs are not part of the BSS and are therefore freed from justice requirements, as liberal egalitarianism explicitly takes the BSS as its primary subject. Basic institutions are organized to distribute primary goods fairly and then maximize the possibilities of private agreements in the economic sphere. Contractual freedom applies notably to CIs, the rules of which are determined by the minimal constraints necessary to secure private voluntary agreements between agents, be they shareholders, executives, employees, suppliers, customers or corporations as moral persons. This first hypothesis is congruent with the conceptualization of the corporation as a nexus of contracts (Fama and Jensen 1983) and of corporate law primarily as a set of voluntarily self-imposed rules (Maitland 2001: 131) resulting from negotiations between the corporation and its shareholders or employees, based on their respective preferences and contributions to the firm's value (Boatright 2004). ${ }^{7}$

Yet this hypothesis is not fully satisfactory. First, it may be internally inconsistent with the Rawlsian framework since Rawls himself suggests that the regulation of some CIs may be required if the absence of CIs' regulation were to bear some unwanted consequences for the fair value of equal political liberties. For instance, he hints that workplace democracy might impact the fair distribution of political liberties and thus be considered a part of the BSS (Rawls 2001: 178). Second, Rawls 
assumes that the ownership of productive assets is an element of the BSS when he compares the fairness benefits of socialism to those of private-property regimes (Rawls 1999b: 6, 242). Why should other CIs fall into a different category?

It may be, however, that CIs should not be excluded from the BSS as a matter of principle and that Rawls's silence on the matter deserves further clarification. Is their absence from the BSS merely neglectful on Rawls's part? Or does Rawls assume that most CIs bear no significant effect on the distribution of primary goods and can therefore be safely ignored by political philosophers and lawmakers? We suggest that the latter is the case for Rawls in the context of a healthy WS: a fully fledged WS that guarantees effective policies of redistribution renders unnecessary the regulation of most CIs; such a WS model was indeed conceivable considering the political and socio-economic landscapes in Western countries in the early 1970s (see section 1 supra). One important implication is, therefore, that the withdrawal of the WS prompts a reassessment of the status and role of CIs. Another equally important implication is that the question of CI status cannot be answered entirely a priori. It is, rather, a partly empirical question, the answer for which depends both on the a priori criteria for the inclusion of institutions in the BSS and the contingent socio-historical states of affairs. Let us now consider the criterion for including an institution in the BSS.

\subsection{In Search of a Systemic Criterion for the Basic Structure's Boundaries}

Identifying institutions belonging to the basic structure of a given society can be a difficult task. Despite its apparent simplicity, the Rawlsian dichotomy of the "main elements of the economic and social system" on the one hand, and the "rules and practices of private associations" (Rawls 1971: 7-8) on the other, is confusing and prompts further clarification. Rawls acknowledges the problem and recognizes that "the concept of the basic structure is somewhat vague" (Rawls 1971: 9).

The socio-economic structure is clearly subject to imperatives of justice as a whole, that is, as "one scheme of cooperation." However, the socio-economic system may be considered as consisting of sub-systems, such as production and trade on the one hand and welfare institutions on the other. The domain of production and trade may itself be subdivided into more specialized components, such as macro-economic policies, market regulations, the legal structure of corporations, the laws and codes that define their rules of governance, and other internal codes and policies. We observe a continuum that goes from macro- to micro-structures. Where does the BSS end, and where do secondary or private institutions begin? At this point it is useful, and perhaps necessary, to have a clear criterion to distinguish the boundaries of the BSS and thus allow the implementation of justice requirements through policy making.

Samuel Freeman offers a functional criterion for identifying elements of the BSS: the latter should be "necessary for productive social cooperation, and hence for the continued existence of any society, particularly any relatively modern one" (Freeman 2007: 102, italics in original). This criterion excludes from the BSS, according to Freeman, universities and the mass media. Similarly, Heath, Moriarty, and Norman assess the relevance of institutions for the BSS by their "centrality ... 
in securing "social cooperation over time"' (Heath, Moriarty, and Norman 2010: 432). This functional criterion is, however, prone to multiple interpretations. For example, Heath, Moriarty, and Norman are willing to include "at very least, publicly traded corporations," but it is unclear which other organizations are eligible and which are not. One may also want to argue against Freeman that universities are essential to economic cooperation because they provide firms with their required educated workforce. More fundamentally, this criterion omits emerging structures and institutions, such as widespread corporate practices or intra-industry selfregulations and other soft laws, which may come to exert a notable effect on the overall distribution of primary goods yet remain functionally nonessential to social cooperation. By contrast, Taylor considers social unions (eg, private corporations) to be part of the BSS: if "the offices and positions associated with them require a major and usually dominant commitment of time and energy and act as the primary sources of livelihood for those who hold them." Such entities include "governments, private and public corporations, universities, NGOs, and so forth" (Taylor 2004: 341), a list notably different from Heath, Moriarty, and Norman's. Finally, O'Neill (2009) includes corporations in the BSS because they are legal conventions having a profound effect on the distribution of primary goods, an angle yet again different from Freeman's functional perspective but which similarly omits emerging informal structures having a profound effect on people's lives. These definitions of BSS are problematic not merely owing to their differences and inconsistencies; rather, it is that the functional and legal approaches share a restrictive conception of the BSS inconsistent with some of Rawls's own purposes. While it is true that Rawls himself sometimes refers to the BSS as a legal framework or functionally essential institutions, he also justifies the BSS as the subject of justice because its effects are profound and pervasive (Rawls 1971: 96).

These inconsistencies can be overcome, however, if we choose another criterion: an element (be it a set institution or an emerging one, a legal rule, a practice, a private organization, and so on) must be included in the BSS if and only if it has a systemic ${ }^{8}$ influence on the distribution of primary goods, i.e., this element affects the expectations of primary goods associated with at least one relevant social position. A relevant social position is one that is not entered into voluntarily and for which the associated expectations of primary goods are therefore inescapable. ${ }^{9}$ This criterion prompts the inclusion of all (and only) the elements that affect:

- the expectations for any relevant social position (or "representative man") of (i) basic rights and liberties; or (ii) freedom of movement and free choice of occupation and/or

- the expectations for the worst off social position of (iii) powers and prerogatives; (iv) income and wealth; or (v) the social bases of self-respect. ${ }^{10}$

This criterion applies to the established and well-known elements of a society's basic structure. Freedom of speech provides one example of a well-identified element that inescapably affects all relevant social positions. Policies of redistribution that affect the worst off social position offer another such example. It is, indeed, because both free expression and redistribution bear social systemic effects and shape the distribution of primary social goods that it is both legitimate and neces- 
sary to subject them to public reasoning and consider them elements of the BSS, and, therefore, subject to the demands of justice.

Our proposed criterion encompasses a fortiori the situations covered by Freeman's functional criterion; the absence of functionally necessary institutions would jeopardize the existence of society, and, with it, all relevant social positions. Our proposed criterion also discriminates between smaller corporations, which typically have little impact on relevant social positions, and bigger corporations (or unions of small corporations), which may bear systemic effects. Moreover, our proposed systemic criterion takes into account institutions spanning the boundaries of individual corporations, such as trade unions or industry-level workers' committees. Importantly, this criterion also allows some emerging institutions, that may not have been previously identified in the law, to be integrated into the BSS.

We believe our proposed criterion accommodates the view of Hsieh (2005) and Moriarty (2005) that voluntariness (and, by implication, exit costs) is a crucial aspect for consideration when shaping the BSS from a liberal egalitarian perspective. We would refine their voluntariness criterion, however, by distinguishing cases in which exit costs affect the (reasonable) expectations of primary goods (such as power and prerogatives, or income and wealth) over the complete life of the most disadvantaged members of society. While the dismissal procedures for top executives do not satisfy our systemic criterion, the dismissal procedures for low-wage workers may do so, especially within the context of weak welfare institutions.

To recap, an institution (corporate or otherwise) belongs to the BSS if and only if it has a systemic influence over the distribution of primary goods, that is, if it affects the expectations of primary goods for a relevant social position. We now examine the systemic effects born by some CIs.

\subsection{Corporate Institutions and the Basic Structure: The Philosophical Import of Empirical Elements}

According to the above criteria, the practices and rules that have an influence on a relevant social position should be included in the BSS. Determining whether and when CIs meet these criteria requires empirical enquiry.

\subsubsection{When Is a Corporate Institution Part of the Basic Structure?}

More often than not, firms' business decisions, such as choices relating to the development of a product or the location of a factory, do not satisfy our proposed criterion of inclusion within the BSS. Typically, the effects of these decisions do not contradict the principles of justice by violating the basic rights of all or the expectations of wealth and power for the worst off. They bear only a local and escapable effect on clients (whenever they can switch suppliers or abstain from the product), employees (whenever they can switch employer or collect decent benefits), and so on. Moreover, no evidence exists to indicate that any of these decisions or processes considered as a whole produce any predictable systemic effect on the distribution of primary goods. A well-ordered society can therefore accept decision-making practices oriented towards instrumental rationality and bound to distinctive purposes or conceptions of the good. This is arguably what Rawls means when he suggests 
that the difference principle does not apply to the transactions or to the decisions of individuals and private associations (Rawls 1971: 8).

However, as soon as some practices, codes, or laws satisfy the systemic criterion, that is, produce some profound and inescapable effects on the expectations of primary goods associated with a relevant social position, they should be considered part of the BSS, despite their private individual or corporate origin. We believe this line of thought is congruent with Rawls's remark that "while churches can excommunicate heretics, they cannot burn them" (Rawls 2001: 11). Indeed, a person excommunicated by a church (in a religiously pluralist state) can still expect a fair share of primary goods from other social institutions, religious or otherwise. This is obviously not the case for a person burned alive.

It follows that the BSS encompasses more than institutions defined or identified a priori as key institutions. It also extends to some real socio-economic structures, the development of which is, to a large extent, spontaneous. The purpose of Rawls's recommended continuous adjustments to the BSS is therefore twofold. One, these adjustments are meant to correct from within the existing structure's frame (for example, the modification of income tax), or the imbalances resulting from the multiplication of transactions that may be fair in and of themselves (Rawls 2005: 284). Two, continuous adjustments also allow integration into the BSS of those practices or institutions that were previously insignificant but that now have distributional effects on a relevant social position.

Consider, for instance, that an analysis were to indicate that regulating some corporate decision-making processes (for example, the composition, structure, and internal workings of strategic boards or human resources [HR] departments) bore an effect on the least advantaged position's share of primary goods, for instance, on the social bases of self-respect or income and wealth. ${ }^{11}$ These practices would be socially structuring although they had not (yet) been formally recognized and regulated as elements of the BSS. Such elements of corporate activity should consequently be treated, along with the property of productive assets, as part and parcel of the BSS.

Our understanding of the BSS may thus appear close to that of Cohen (2008), because we also include informal structures in the BSS. Yet we draw a different conclusion from Cohen's: we propose that the unfair effects of informal structures must be addressed by the legislature rather than by an ethos of justice informing individuals' personal choices. Furthermore, it must be noted that any new regulation targeting emerging practices should still respect the lexical priority of the first principle over the second. In other words, a practice detrimental to the worst off might well be forbidden or, simply, regulated, provided the regulation rests within the bounds of fundamental liberties and fair equality of opportunity.

\subsubsection{Do Corporate Institutions Bear a Systemic Effect on the Distribution of Primary Goods?}

Whether corporate rules can actually affect the distributional justice of an organization, an industry, or a society overall has been a matter of scholarly debate among economists. In reaction to the progressive corporate law movement, Maitland argues that corporations' rules, such as job security, are distributionally neutral for their 
employees (Maitland 2001: 131). He reasons at the level of one organization and regards corporate rules as negotiated agreements. Basically, stockholders will seek compensation for any new rule beneficial to workers and detrimental to themselves, either by lowering wages or by exiting the industry for better returns elsewhere. As a consequence, the introduction of worker-friendly corporate rules would not make employees better off in the long run. While agreeing with Maitland on the distributional neutrality of rules that affect a "small" part of the economy, Beck responds that rules affecting a "large" part of the economy may nonetheless bear distributional effects (Beck 2005). In his discussion of both Maitland and Beck's arguments, Witztum focuses on a job-security rule. Departing from both Maitland and Beck, he argues that such a rule, both when mandated at the level of a small industry and when enforced across industries, may have wider social distributional effects. In the case of a small industry without any influence on labor markets, corporate rules beneficial to workers have a re-distributional effect, albeit at the industry level only and at the cost of reduced industry size. However, once the rule applies to a sufficiently large industry or across industries, it has a distributional effect on society overall and operates transfers from stockholders to workers. The sector size determines only the "magnitude of the re-distribution" (Witztum 2008: 98). However, a downside is that the labor supply, and hence the total material output, may be reduced. Yet, Witztum argues, such allocation may be socially more desirable than the allocation that maximizes global utility. In Rawlsian terms, the proposed corporate job-security rule is acceptable and indeed desirable if it improves the situation of the worst off, eg, poor workers, despite entailing possibly detrimental effects for overall utility.

\subsubsection{Does the Philosophical Status of Corporate Institutions Depend on}

Historical Factors?

Our arguments are consistent with Witztum's. However, we consider the importance of major political and economic changes that influence assessments of CIs' effect on the distribution of primary goods. We are therefore broadly sympathetic to Heath, Moriarty, and Norman's (2010: 430) call for interdisciplinary projects that inform the understanding of political philosophers. We also believe that political philosophers cannot ignore the empirical observations made by their colleagues in the social sciences. An important implication of our paper's argument is that a statement made by political philosophy on, say, the justice of a set of institutions, can be true during a certain epoch and false at a later date because the empirical circumstances surrounding that set of institutions has changed.

Significant political and economic transformations have, arguably, occurred over the last forty years or so. From among these, in section I we characterized the withdrawal of the WS as a broad historical event that has affected several developed countries and followed different, though equally declining, trajectories. In Rawlsian terms, one might say that the developed countries we surveyed in this paper's first section, and which were once characterized by robust WSs, have moved closer to the ideal form of WS capitalism. If a lead is taken from our argument that the BSS comprises elements bearing a systemic effect on relevant social positions, then an 
assessment of the implications of the WS's historical decline for the systemic distribution of primary goods, and the delineation of the BSS, is prompted. Because a detailed analysis of the application of our argument for each primary good is beyond our scope here, we illustrate our argument for a single primary good, namely the social bases of self-respect, and its import for democratic CIs. This choice is prompted by Rawls's consideration that the social bases of self-respect are "perhaps the most important primary good" (Rawls 1971: 440). We believe, however, that the gist of our argument for self-respect is equally relevant to other primary goods, such as powers and prerogatives or income and wealth, and to other CIs.

\section{ILLUSTRATION: OPPORTUNITIES FOR MEANINGFUL WORK AND WORKPLACE DEMOCRACY IN A WEAKENED WELFARE STATE}

In this section we illustrate some of the implications of our argument on the import of the decline of the WS for the BSS's boundaries. We argue that the WS's decline prompts reforms for CIs on two distinct, though related, fronts: the organization of opportunities for meaningful work (thereafter, OMW) and participation in decisionmaking (participatory CIs). We now undertake three tasks: first, we examine whether and why OMW constitutes a condition for self-respect in a well-ordered society; second, we assess the impact of the decline of the WS on CIs conducive to OMW; and third, we examine further implications of the WS's decline for participatory CIs.

\subsection{Opportunities for Meaningful Work and Self-Respect}

We first consider arguments in favor of an extension and refinement of the legally enforceable regulation of CIs in the name of one primary good: the social bases of self-respect (or self-esteem). Self-respect may be broadly defined as "a matter of recognizing and living appropriately in the light of standards one . . regards as important" and is often connected to the idea of one's status or dignity as a person (Moriarty 2009). Self-esteem, by contrast, is "a matter of thinking positively of oneself" (Moriarty 2009). Our argument holds both for self-respect and self-esteem, but we agree with Moriarty (2009) that although self-respect and self-esteem are different notions, Rawls fails to distinguish between them in $T J$ when he defines interchangeably "self-respect (or self-esteem)" as a sense of one's own value, the value of one's life plan and an associated confidence that this value can be actualized:

[S]elf-respect (or self-esteem) . . . includes a person's sense of his own value, his secure conviction that his conception of his good, his plan of life, is worth carrying out. And second, self-respect implies a confidence in one's ability, so far as it is within one's power, to fulfill one's intentions. (Rawls 1971: 440)

While the latter account has often been interpreted as an account of self-esteem, Rawls explicitly mentions the importance of self-respect in later writings:

[the social bases of self-respect] are features of the basic structure that may reasonably be expected to affect people's self-respect and self-esteem (these are not the same) in important ways. (1999a: 260) 
Of note, justice aims to provide only the social bases for self-respect (i.e., its institutional conditions) not directly shape people's attitudes and feelings.

We advocate inclusion into the BSS of key aspects of CIs-namely, workplace democracy - in the context of a declining WS, to guarantee the social bases of self-respect, from the perspective adopted by Rawls in Justice as Fairness (JAF). In $J A F$, Rawls considers the social bases of self-respect secured if citizens can see themselves as free and equal people able to pursue their conception of the good independently of its substantial content. How can we build a Rawlsian public policy on the formal idea that all activities must be considered part of at least someone's conception of the good? ${ }^{12}$

In $J A F$, Rawls institutionalizes the social bases of self-respect through the two principles of justice and the way they guarantee a fair distribution of the other primary goods, as well as the public recognition of those principles (Rawls 2001: 60). But little is said about corporations, except the mention of an opportunity for meaningful work in the preface to the 1996 paperback edition of Political Liberalism (PLP), as has been astutely spotted by Moriarty (2009: 446). In Rawls's short statement, this opportunity should be secured by "society as employer of last resort through general or local government, or other social and economic policies" (Rawls 2005: lvii). In the remainder of the section, we examine ways of securing OMW through policies promoting democratic CIs.

Self-respect, and its implications for work and CIs, have received much attention from Rawlsian scholars in recent decades. ${ }^{13}$ We take our lead from Moriarty (2009), both because we share his overall review of previous accounts and because his rigorous reconstruction of Rawls's account of OMW offers a starting point for our argument concerning CIs. Moriarty examines the significance of the appearance of OMW, as a basis of self-respect, in PLP. Through a close analysis of Rawls's writings and some careful hypothesizing, Moriarty characterizes meaningful work as complex, varied, and involving "considerable decision-making power." He also suggests that the OMW must be satisfied in the work sphere, as opposed to non-work private associations because, Moriarty hypothesizes, "people's participation in work associations . . is . . mandatory and extensive." Finally, he speculates that Rawls mentions the state as the purveyor of OMW in PLP because, "while in Theory Rawls may have hoped that a society structured according to his two principles, including fair opportunity, would provide citizens with enough meaningful work, by PLP he seems to have accepted that it might not" (Moriarty 2009).

We suggest that meaningful work should be understood in post-Theory works as work congruent with people's conception of the good rather than as necessarily complex or refined work. Our analysis of the BSS in section 3 (see above) also adds to Rawls's reconstructed account of OMW the idea that the state's role, and the philosophical status of CI for OMW, must be contextualized within the wider socio-political institutions of the considered society ${ }^{14}$ and, in particular, its WS. We suggest that the stronger the WS, the stronger the probability that individuals have chosen the social position they occupy, and that they therefore live and work by their conception of the good. ${ }^{15}$ Since Rawls's realistic utopias seek to take account of the material constraints set on societies, we shall make our point by examining 
two plausible contingent scenarios: one of relative material abundance and limited inequalities, and one of lesser material abundance and greater inequalities.

\subsection{The Welfare State's Significance in Opportunities for Meaningful Work: Two Realistic Scenarios}

Let us first consider a well-ordered society in a situation of relative material abundance and limited inequalities. It can be argued that Rawls could safely avoid the issue of inappropriate (that is, not meaningful) forms of labor since unworthy professional activities and working environments are bound to disappear from a wellordered society under propitious circumstances. The form of egalitarianism resulting from application of the principle of difference would attenuate power and domination relations in the labor market. A Painean system of redistribution, warranting a substantial, unconditional basic income (Van Parijs 1995), appears to be the most appropriate WS regime for this purpose. Such a system reverses the commodification of labor-power (Esping-Andersen 1990), and allows the individual to choose freely between paid or unpaid activities. Work contracts are therefore signed voluntarily, and between equals. Individuals would no longer have to accept degrading activities and working conditions. Should they subsist, organizations' authoritarian practices and internal hierarchies would not present a threat to self-respect. Submission to these hierarchies would constitute a real choice in the context of a rational plan of life, as is the case, for instance, when someone joins a religious community or the army. Moreover, two solutions would be available in the likely event it became difficult to recruit workers willing to perform the most unattractive tasks: the financial rewards associated with these tasks would increase sharply in a well-ordered job market, or these tasks could be distributed equitably among all able members of society. Under these circumstances, the WS secures OMW and, therefore, a fair distribution of the social bases of self-respect since people may indeed decide to live as they choose, by their conceptions of the good. The individuals' equal status as moral agents is thereby honored. Furthermore, their sense of their own value and the belief that their projects are worth pursuing are likely to be strengthened, as well as their confidence in their ability to achieve their projects.

Consider now societies remote from an equalization of conditions, and in which the worst off receive scant resources from redistribution. This inequality may result from lack of citizen support for justice principles—what Rawls calls the "subjective circumstances" of justice_-or be due to external constraints on societies' redistributive abilities — the "objective circumstances" of justice (Rawls 1971: 126-27)—such as those mentioned in section 1.2: global competition between countries to attract investment and firms; the breakdown of the Keynesian consensus at the nation-state level; and the resulting financial crisis of WSs.

In this situation, the conditions for the vanishing of unworthy tasks and authoritarian hierarchies are not met (see Fleurbaey $2006 \mathrm{~b}$ for a study of such imperfect conditions). When markets are granted priority for the allocation of jobs, many individuals accept poor roles in conditions of undue economic constraint. Thus, a significant number of persons occupy roles not of their choosing or that they find 
unworthy, uninteresting, underpaid, set in authoritarian working environments, or simply difficult to reconcile with their private conception of the good. In such conditions, it is doubtful that citizens will consider these activities constitutive of their life plan or that they will be able to find some association that can confirm and reinforce the activities' social value or interest (Guillarme 1999). Furthermore, it becomes increasingly difficult, if not impossible, to make a (modest though decent) living by working part time at a meaningless job while dedicating one's free time to meaningful unpaid activities in such associations as chess clubs, softball teams, or charities. In other words, work tasks not chosen by the individual may not be subsumed under anyone's conception of the good. The distribution of the social bases of self-respect would be unacceptably unfair if one could think of another social system that might make the least advantaged better off in terms of OMW. For, in such circumstances, the worst off seem to be considered as means rather than as ends, likely affecting their project's, and their own, sense of value.

This might be the reason why Rawls suggests in PLP that the state should be the employer of last resort. It is worth noting that, as Rawls doubts that the WS may provide adequate OMW, he hesitates to draw any implications for corporations and still relies on the state as employer. Our analysis departs from Rawls on this point. For how would the state know better than the employees themselves, or their elected, well-informed, and accountable representatives, what exactly is meaningful to them? We would propose that democratic CIs may provide for OMW better than public employment in the context of a weak/ening WS and therefore be explicitly treated as an element of the BSS. A professional activity structured and enforced democratically will be more easily regarded as a dimension of a rational life plan: indeed, either it allows workers to pursue as far as possible their conception of the good in their work activities, or it ensures that their interests for their particular conception of the good get represented in higher decision-making processes. Because an individual's choice for a particular activity cannot be considered with confidence as the outcome of their moral capacity for pursuing a conception of the good, some room needs to be made within the activity for exercising that capacity. ${ }^{16}$ The WS's absence or weakness implies a greater number of people for whom OMW must be guaranteed through democratized CIs. ${ }^{17}$ In this context, it becomes all the more pressing to mandate democratic CIs by law because the least favored can no longer resign from their firms without incurring unreasonable penalties. Otherwise, jobs that already lack meaningfulness tend to become even less meaningful whenever the degradation of labor conditions is able to increase the firm's profitability without incurring overwhelming legal penalties.

\subsection{Beyond Opportunities for Meaningful Work: The Welfare State's Significance for Participatory Corporate Institutions}

Our substantial conclusions may also be reached through other arguments, such as those based on the bare assumption that participatory CIs are always necessary in industrial societies. Indeed, a number of other Rawlsian arguments amenable to workplace democracy have recently been developed (Hsieh 2008b; Hussain 2009, 
2012; O’Neill 2008; see also Hsieh 2008a for a comprehensive survey). First, along with the liberty of conscience and freedom of association, the "freedom to take part in economic decision-making" (O’Neill 2008: 35) may be considered a fundamental freedom necessary to sustain citizens' two moral powers: their sense of justice, and their capacity for developing a conception for the good. Democratic participation at work could foster the deliberation and reasoning abilities that citizens need when deliberating justice at the national level. Participation at work also trains workers' moral agency and sustains their capacity for developing a conception of the good (O'Neill 2008: 35-36). Second, by fostering the moral powers that people need for playing their full role as citizens, workplace democracy supports a stable polity (O’Neill 2008: 42-43). A related yet distinct argument suggests that a "democratic corporatist regime," in which employees participate in regulating the part of the economy in which they are involved, would strengthen their commitment to justice as they come to realize the effects of their particular sector and its regulation on the overall fairness of society. Hence, "democratic corporatism" would be necessary to guarantee the moral ideal of stability (Hussain 2012; see also Hussain 2009). ${ }^{18}$

Yet, as we noted earlier, such assumptions were missed by Rawls himself and might be debated by Rawlsians who believe that people can foster their sense of justice through other associations, such as in church or activist groups (for critical assessments, see Schwartz 1982: 636-37 and O'Neill 2008: 41-42).

The argument we developed in this section, however, allows the reconciliation of both views by attending to the historical context that prompts the inclusion or exclusion of CIs into the BSS on the basis of their effects on self-respect and citizens' moral powers. While we do not review each argument's validity for participatory CIs, we emphasize that those arguments against the imposition of democratic CIs assume the existence of a strong WS. In such a context, the possibility of developing one's moral agency, as well as one's ability to engage as a citizen in the political sphere, may be secured through engagement in purposefully chosen associations and work organizations. This is less likely to be the case when the WS is weakened. In other words, while it is beyond our scope here to draw a conclusion on ahistorical assumptions about democratic CIs, we make instead the philosophically more modest, yet important, point that some contested arguments for democratic CIs cannot continue to be a matter of debate once we take into account the weakening WS in order to clearly identify CIs as an element of the BSS.

To recap this section's argument: the WS's decline dilutes the conditions for participation in an economic life compatible with people's life projects, thereby threatening the self-respect of the worst off. It also threatens people's moral powers. In turn, this prompts a restructuring of non-democratic work organizations. The institutional bases for a fair distribution of the social bases of people's self-respect and moral powers are transferred from the WS onto CIs. It may be argued that such reforms are redundant in a fully fledged WS offering real alternative opportunities; such reforms become essential in the face of the WS's decline, however. 


\section{DISCUSSION: POTENTIAL OBJECTIONS TO AND EXTENSION OF OUR ARGUMENT TO OTHER PRIMARY GOODS}

\subsection{Should We Advocate Democratic Corporate Institutions, or the Restoration of the Welfare State, or Both?}

Our argument implies the rather trivial idea that societies refusing both democratic CIs and a fully fledged, labor decommodifying WS are further from a well-ordered society than societies including at least one of these provisions. Less trivially, our systemic criterion for including institutions in the BSS also indicates that a number of CIs that might have been left to private agreement in a fully fledged WS must be regulated in its absence so as to impede unfair effects on the distribution of primary goods.

Our argument does not allow, however, the adoption of a position as to whether democratic CIs offer a fairer or a more feasible solution than does a fully fledged WS. Yet this open alternative does imply that those advocating fairness while feeling reluctant towards the WS should also consider the costs associated with more democratic CIs and vice versa. The costs of OMW and participatory CIs for corporations and their owners should not be compared with a scenario in which there are few taxes on corporations and wealthy individuals. Rather, the costs of OMW and participatory CIs should be assessed against an equally fair scenario in which heavily progressive taxes support a fully fledged WS. Conversely, if the costs of a fully fledged WS seem a heavy burden to shareholders and strategic managers, they should be reminded that, for them, the alternative implies a loss of control within CIs.

It may also be objected that a fully fledged WS is not sufficient on its own and that its hypothetical restoration would still prompt the inclusion of a wider than current range of CIs into the BSS. Our own stance on this point is conventionally Rawlsian, and we would maintain that in a fully fledged WS, there would be room for authoritarian corporations provided they do not systematically affect the distribution of primary goods. It is an empirical question as to whether contemporary authoritarian organizations systematically affect the distribution of primary goods. It may well have been the case that at the time of Rawls's writing that non-democratic corporations had a deeper systemic impact than he believed. Our stance is not taken relative to the 1970s-1990s period, but we do maintain that in the current context of weak WSs, non-democratic corporations bear a negative systemic effect, prompting the integration of further CIs into the BSS.

\subsection{Should Democratic CIs Be Enforced through Mandatory Rules or through Tax Incentives?}

While our arguments are largely expressed in terms of compulsion and mandatory rules, we would not exclude the possibility of reaching similar (and in certain cases, better) results by resorting to a policy of financial incentives and penalties. As indicated in section 3 (see above), we view the domain of political philosophy as being concerned with enforceable rules. Nevertheless, such rules can perfectly 
well encompass financial/tax penalties or competitive disadvantages for firms that decide to sacrifice their contribution to overall fairness for revenue. Moreover, whether mandatory regulation is more efficient or better accepted than tax incentives is largely an empirical matter depending on each country's business culture and history and the specifics of the concerned activity sectors. Our overview of WS regimes, above, somewhat suggests that tax incentives are likely to be more easily accepted in the US, whereas mandatory regulation might be comparatively easier to implement in Europe's corporatist and social-democratic regimes.

\subsection{Is Our Argument Sustainable in a Globalized Economy?}

Some may object that our proposal is unrealistic within the context of a globalized economy. For instance, Boatright argues that the near absence of corporations owned or managed by workers in free-market economies reflects the inefficiencies of such corporations, especially when monitoring workers and raising capital, as well as in relation to their transaction costs (Boatright 2004: 6-9). Therefore, democratic CIs will not be adopted unless they are made mandatory. However, this tactic may in turn raise competitiveness issues relative to countries without similar legislation (Beck 2005, Boatright 2004: 9, Witztum 2008). Other corporate rules, such as Witztum's proposed job security, may also increase the marginal cost of products, unless workers increase their productivity in return for the extra benefits. Classical economics suggests that the latter is unlikely because employees perceive benefits as unrelated to individual efforts. Therefore, corporate rules propitious to social welfare may also alter a country's competitiveness (Witztum 2008: 107). If this proves true, the very reason behind the WS's decline (namely, globalization) might also constrain the adoption of corporate rules beneficial to workers.

These are fair and important concerns that have received well-deserved attention. The inefficiency of democratic CIs has been disputed, however. In a paper arguing for a stronger employee voice in CIs, McCall (2001: 201) reviews literature suggesting that participatory management practices have either a positive or neutral impact on productivity and profitability. As for the consequences of job security and other social welfare rules, Witztum envisages that individuals might not behave in accordance with classical economics expectations. He contemplates the possibility that employees might sustain a steady labor effort, and hence maintain stockholder return, out of gratitude for the very benefits provided by job security and other social welfare rules, even though such benefits are perceived to be unrelated to individual efforts. Offering a full and conclusive assessment of this controversial issue goes beyond our current scope. ${ }^{19}$

For our analysis, it is sufficient to say that it is necessary to consider the regulation of CIs within the context of a declining WS. Without concluding whether global constraints have a bearing in exactly the same way on CIs and WS policies, we hypothesize that this might not necessarily be the case. The financial strain on the WS is largely related to multinational corporations avoiding high corporate taxes through transfer pricing and other evasion instruments. Under such circumstances, more democratic CIs could complement welfare policies with regard to self-respect 
because multinationals might well prove less reluctant to establish more democratic CIs than they are to submit to taxes that slash their benefits without providing the advantages of a committed workforce. Furthermore, participatory CIs might indeed be preferred over welfare policies by citizens themselves in situations in which citizens resist fair taxes and welfare transfers. Democratic CIs may then prove to be more stable than welfare benefits for the purpose of ensuring self-respect in the long run and, hence, be a better choice. Finally, even if such reforms were difficult to implement at the level of smaller states, this might not be so at a higher level, eg, at the European Union or the US federal level, as it is unlikely that investors would flee such large markets (see McCall 2001 for a similar argument centered on the US). To recap, our response to the globalization argument is that the legal enforcement of our proposed CI reforms provides a viable alternative, one that preserves corporate competitiveness while respecting the Rawlsian principles of justice. Legislation on CIs could complement taxation fruitfully for the purposes of a fair distribution of self-respect.

\subsection{Can Our Argument Be Extended to Other Primary Goods?}

So far, we have argued that an enhanced and legally enforceable representation of the most vulnerable employees in the governing and managerial institutions of corporations could counterbalance the negative influence of the withdrawal of the WS on the social bases of self-respect. Can this argument be extended to other primary goods, the distribution of which is regulated by the second principle of justice?

As we indicate in the second section of our paper, the second principle of justice is meant to offer a criterion of fair distribution both for the social bases of self-respect and for other primary goods, such as powers and prerogatives, or income and wealth (Rawls 2001: 58-59). Our argument for self-respect can be extended fairly simply to powers and prerogatives: enforcing employee participation reinforces, by the same token, their powers and prerogatives beyond what they would obtain in the absence of a strong WS. Many of the powers and prerogatives usually reserved for the privileged group of management would be shared with the less favored groups of line workers and office clerks.

We now examine the import of enforcing democratic CIs on income and wealth. In a fully fledged POD, income and wealth include salaries, resources from the WS, and well-dispersed productive assets and their dividends. A high level of income transfers will position citizens on a near-equal footing in the job market, especially in relation to salary negotiation, and limits the capacity for capital accumulation, thereby leveling revenues from capital. In such a context, the question of the governance of HR or personnel departments is marginal and can be left to private agreement. Here again, in light of the difference principle, the decline of the WS in contemporary societies prompts a re-examination of the suggested balance between welfare action and CIs.

A specific focus on the primary good of income and wealth directs our attention to the role and import of HR departments, among other CIs. We hypothesize that democratic and transparent decision-making processes in HR departments should 
level pay gaps within corporations and, more generally, within society. In the current (undemocratic) situation, employees earning low salaries can always try to weigh in on the HR or personnel director by threatening to vote with their feet: a very light threat in the context of a weak WS. However, if the position of HR director were open to election by employees, or if employees could weigh in on the HR director's appraisal and remuneration, bargaining power within the corporation would be more balanced.

This suggestion raises a difficulty that we should mention without offering a fully satisfying answer in the context of the present paper. What about those affected by the decisions of a corporation without being employed by it? The democratization of the corporation, understood as the inclusion of workers and their interests in the firm's decision-making processes, might well improve the situation of employees while weakening that of those whose interests are affected by the actions of the corporation but have not been included in the debates affecting them. The unemployed constitute one such group since they are likely to be penalized by a policy of high salaries that would increase the price of commodities while maintaining a significantly high level of unemployment. This example is open to two possible interpretations that are not mutually exclusive. One possible implication is that corporate decision-making should include representatives of those groups most affected by the corporation's decisions. We can, however, anticipate some difficulties being raised by the initial implementation and continuous operation of such a system (Edward and Willmott 2008). Alternatively, it might be argued that the difficulty of including external stakeholders reinforces the case for the preservation of a level of national solidarity and coordination in spite of the technical difficulties brought about by the current lack of political control over the globalization of economies and societies. More specifically, this interpretation may imply that within the context of legally enforced worker participation, a substantial portion of taxes should be spent for those who are excluded from participatory CIs.

\section{CONCLUSION}

We propose that the decline of the WS prompts a revision to the boundaries of the BSS so as to include CIs. Our Rawlsian approach attends to the requirements of the principles of justice that define the distribution of primary goods. For this purpose, we offer a criterion that clarifies which institutions belong to a society's basic structure: an institution belongs to the BSS if and only if it bears an effect on the expectations of primary goods associated with a relevant (that is, non-voluntary) social position - what we designate as a systemic effect on the distribution of primary goods. We then propose, in agreement with Rawls's theory yet beyond his explicit statements, that a number of (currently missing) institutions of the private sector should be regulated by law for the purposes of justice because they bear a systemic effect on the least advantaged positions in society-especially in the current context of weakened WSs. In such a context, CIs are elements of the BSS and can neither be left to the good will of corporate members nor to a corporate law that would ignore justice principles. Instead, they are a topic for public reason and 
must be shaped with regard to justice rather than mere efficiency. These regulations on corporations must be enforced by law rather than be considered options for selfregulation. Here, we have particularly focused on the primary good of self-respect; however, we believe our proposed ideas can relatively easily be extended to other types of primary goods, such as income and wealth, or powers and prerogatives.

In the context of a weak WS, features distinguishing economic organizations from states (Hsieh 2005, Moriarty 2009, O’Neill 2008) no longer hold: the least favored citizens are no longer free to choose whether or not they wish to join a corporation. They are indeed in a position to choose one corporation rather than another, yet they must chose one if they are to subsist. A significant number of citizens are obliged to live a professional life that negates their own rational life plan. This situation is unfair when we have the option to either make legally enforceable provisions at the level of the corporation to guarantee a fair redistribution of primary goods, or reinstate the WS. Our paper does not adopt a position as to which of these policies is the most realistic, yet justice as fairness does require us to achieve one of them or, indeed, a combination of both.

\section{NOTES}

For their helpful comments on early drafts of the paper or discussions of some aspects of the issues it deals with, we are grateful to Bob Audi, Marie-Laure Djelic, Olivier Favereau, Marc Fleurbaey, Axel Gosseries, John Hendry, Kei Hiruta, Hervé Pourtois, Baudoin Roger, Julian Savulescu, as well as the participants in the Oxford Applied Ethics Discussion Group, the Essec C2G2 Brownbag Seminar, the Bernardins Seminar on Corporate Ownership and Responsibility, and audiences at the SBE annual meeting and the annual conferences of SASE and EGOS. We would also like to thank the audience of the Economic Ethics Network workshop for insightful comments. We are particularly grateful to Alan Strudler (qua Associate Editor) and four anonymous reviewers for helping us revising and strengthening this paper. All remaining errors are our own.

Our research benefited from the support of the Abdul Latif Jameel Community Programs (ALJC); the Independent Social Research Foundation; the Research Programme on Corporate Ownership and Responsibility (College des Bernardins); the Oxford Seminar for Conventions and Rules (OSCAR); the Uehiro Centre for Practical Ethics (University of Oxford). We address our particular thanks to the Centre for Social Ontology, the Essec Center for Capitalism, Globalization and Governance and the Chaire Hoover (Université Catholique de Louvain) for having hosted part of this research.

1. In this paper, we use the word institution in the broad sense of a relatively enduring social arrangement. This includes formal and informal "rules of the game and . . the ways in which those rules are ... played out" (Djelic 2010: 33). Notably enough, institutions are nested within one another. Hence, a private corporation is a corporate institution, but so are its human resource management policies ("inside" the firm) and so are the various laws regulating business ("outside" the firm). This broad conception of institutions is compatible with Rawls's definition: "Now by an institution I shall understand a public system of rules which defines offices and positions with their rights and duties, power and immunities, and the like. These rules specify certain forms of action as permissible, others as forbidden; and they provide for certain penalties and defenses, and so on, when violations occur. As examples of institutions, or more generally, social practices, we may think of games and rituals, trials and parliaments, markets and systems of property. An institution may be thought of in two ways: first as an abstract object, that is, as a possible form of conduct expressed by a system of rules; and second, as the realization in the thought and conduct of certain persons at a certain time and place of the actions specified by these rules" (Rawls 1971: 55).

2. For the sake of our argument, we refer interchangeably to "corporate democracy," "participatory CIs," "democratic CIs," and "workplace democracy." "Democratic CIs" refers to those CIs in which employees have some power over their work, whether directly or indirectly. This encompasses employees' direct participation in strategic and organizational decision-making, including task design. It also includes the representation of their interests on the board (corporate governance). Although the latter is considered 
a distinct practice and field of study, we believe that employee participation and corporate governance both refer to the same question of the allocation of power in work organizations.

3. The distribution of the social bases of self-respect is somewhat complex, since it requires that individuals be able to value their life project in relation to themself and others. Whether their distribution should follow the maximin rule or be equalized as basic rights and liberties, has been widely debated. See Doppelt 1981, Eyal 2005, Moriarty 2009: 444-45, Van Parijs 2003: 211-12.

4. Moriarty argues in his recent paper on Rawlsian self-respect that Rawls's post-Theory bases of selfrespect require an institutionally secured opportunity for meaningful work (Moriarty 2009: 446) along with the fair distribution of other primary goods-equal liberties and a maximin distribution of socio-economic resources. We address this discussion in section 4.

5. Rawls suggests that we consider each of the two parts of the basic structure as dealt with at a different stage — at the conventional stage for the constitution and the legislative stage for social and economic policies:

I imagine then a division of labor between stages in which each deals with different questions of social justice. This division roughly corresponds to the two parts of the basic structure. The first principle of equal liberty is the primary standard for the constitutional convention. Its main requirements are that the fundamental liberties of the person and liberty of conscience and freedom of thought be protected and that the political process as a whole be a just procedure. Thus the constitution establishes a secure common status of equal citizenship and realizes political justice. The second principle comes into play at the stage of the legislature. It dictates that social and economic policies be aimed at maximizing the long-term expectations of the least advantaged under conditions of fair equality of opportunity, subject to the equal liberties being maintained. At this point the full range of general economic and social facts is brought to bear. (Rawls 1999b: 174-75)

6. This paper's argument assumes that contemporary liberal societies are closer to POD than to market socialism. We acknowledge that some refinement would be needed to address the case of market socialism.

7. It is only from the 1970s onwards that various shades of institutional economics rediscovered the early insights of Coase (1937) and developed a conceptualization of corporate contractual relations as institutions rather than mere market transactions (Williamson 1975). One could therefore hypothesize that liberal egalitarian justice was largely deprived from an epistemological grip on CIs also for that reason. We thank an anonymous reviewer for bringing this matter to our attention.

8. We borrow the term from Susan Muller Okin and her discussion in Justice, Gender, and the Family of Rawls's unidentified gender system (Okin 1989).

9. For Rawls, a social position provides, therefore, "an appropriate standpoint for judging the social system" (Rawls 1999b: 82).

10. The distinct treatment of goods (i) and (ii) on the one hand, and goods (iii), (iv), and (v) on the other, is prompted by Rawls's distinction between fundamental freedoms and social and economic inequalities (Rawls 1999b: 53). Primary goods (i) and (ii) are those freedoms which must be made equally available to all positions: "important among these [basic liberties] are political liberty . . . and freedom of speech and assembly; liberty of conscience and freedom of thought; freedom of the person. . . These liberties are to be equal by the first principle" (Rawls 1999b: 53, our emphasis). Goods (iii), (iv), and arguably (v) are those conducive to the socio-economic inequalities that must be regulated according to a maximin or leximin (Van Parijs 2003) principle: "the second principle applies . . to the distribution of income and wealth and to the design of organizations that make use of differences in authority and responsibility" (Rawls 1999b: 53). Their fair distribution depends on the share held by the worst off, as "the difference principle selects one representative for [the] special role" of judging social and economic inequalities (Rawls 1999b: 83): the representative of "the least fortunate group" (1999b: 83). This holds for situations of so-called "closeknitness" (Rawls 1999b: 72), where the expectations of the worst off are connected to those of the better off. We leave aside, as Rawls does (1999b: 72), the complication of assessing situations in which the latter assumption is not verified.

11. For example, large-scale relocations typically affect the least advantaged members of society, whose skills are deemed replaceable by those of other workers located in countries where labor is cheaper. It can reasonably be expected that the representation of unskilled employees in boards of directors and their contribution to the election of HR directors would limit the frequency and negative effects for unskilled workers of such relocations, especially in situations in which the corporation is generating an overall profit. 
12. This idea is close to Van Parijs's criterion of "undominated diversity" (Van Parijs 1995).

13. For useful reviews of prior works on Rawls and self-respect, see Hsieh 2008a and Moriarty 2009: 441n2. Cited works include Cohen 1989a, Darwall 1977, Doppelt 1981, Eyal 2005, Hsieh 2005, Massey 1983, Shue 1975, and Van Parijs 2003.

14. This is arguably compatible with Rawls's statement that:

\begin{abstract}
Eventually in applying the difference principle we wish to include in the prospects of the least advantaged the primary good of self-respect; and there are a variety of ways of taking account of this value consistent with the difference principle. How heavily this good and others related to it should count in the index is to be decided in view of the general features of the particular society ... as seen from the legislative stage. (Rawls 1999b: 318, our emphasis)
\end{abstract}

15. We are grateful to one of our reviewers for asking whether a very low unemployment rate would compensate for the decline of the WS. The problem is that countries with low unemployment rates are not immune to unsatisfying jobs and poverty at work: even if everyone were to get a job, it would not necessarily follow that those jobs would be up to the standards required for self-respect. Assuming otherwise presupposes a confidence in labor-market mechanisms that is at odds with the history of workers' rights. The latter were won through successive struggles rather than through the workings of the invisible hand. Unfortunately, deepening this discussion would take us far beyond the boundaries of the present paper.

16. For instance, in a situation of high unemployment, an employee keen on promoting the defense of the environment might not be able to leave her employer upon hearing of a measure, by her employer, leading to an increase in pollution. The presence of democratic CIs would offer her, however, the possibility to voice her concerns and propose amendments to her firm's projects.

17. Since the Hawthorne experiments in the 1930s, numerous empirical studies have established the links between workers' motivation and their ability to have a voice. See for instance McGregor (1960) and Mitchell (1973). We are grateful to an anonymous reviewer who remarks, however, that since self-respect and motivation are distinct, more empirical work is needed on the effects of democratic CIs on self-respect.

18. A further argument justifies democratic CIs by reference to the difference principle. It contends that the redistributive interpretation of the difference principle, while ensuring a fair distribution of income and wealth, ignores two equally important primary goods: powers and prerogatives, as well as the social bases of self-respect. Additional Rawlsian arguments in favor of democratic corporate governance include those of G. Doppelt (1981), S. Freeman (2007), and N. Hsieh (2005, 2008b). On the importance of workplace democracy for a fairer distribution of powers, see Freeman 2007: 135. For a Rawlsian argument for a basic right to be protected from arbitrary interference at work, from the perspective of a "workplace republicanism" that includes a right to contest rather than a right to govern, see Hsieh 2005 and Hsieh 2008b.

19. Those readers who followed the development of the financial crisis over the 2007-2012 period will have noticed that cooperative banks fared much better than their privately owned rivals.

\title{
REFERENCES
}

Beck, J. H. 2005. "Distributive Justice and the Rules of the Corporation: Partial versus General Equilibrium Analysis," Business Ethics Quarterly 15(3): 355-62. http://dx.doi.org/10.5840/beq200515328

Boatright, J. R. 2004. "Employee Governance and the Ownership of the Firm," Business Ethics Quarterly 14(1): 1-21. http://dx.doi.org/10.5840/beq20041416

. 2006. "What's Wrong—and What's Right—with Stakeholder Management," Journal of Private Enterprise 21: 106-30.

. 2010. "Executive Compensation: Unjust or Just Right?," in Oxford Handbook of Business Ethics, ed. G. G. Brenkert and T. L. Beauchamp, 161-201. New York: Oxford University Press.

Child, J. W., and A. M. Marcoux. 1999. "Freeman and Evan: Stakeholder Theory in the Original Position," Business Ethics Quarterly 9(2): 207-23.

http://dx.doi.org/10.2307/3857472 
Coase, R. H. 1937. “The Nature of the Firm,” Economica 4(16): 386-405. http://dx.doi.org/10.1111/j.1468-0335.1937.tb00002.x

Cohen, G. A. 2008. Rescuing Justice and Equality. Cambridge, Mass.: Harvard University Press.

Cohen, J. 1989a. “Democratic Equality,” Ethics 99(4): 727-51. http://dx.doi.org/10.1086/293119 1989b. "The Economic Basis of Deliberative Democracy," Social Philosophy and Policy 10(2): 25-50. http://dx.doi.org/10.1017/S0265052500000625

Darwall, S. L. 1977. “Two Kinds of Respect,” Ethics 88(1): 36-49. http://dx.doi.org/10.1086/292054

Djelic, M. L. 2010. "Institutional Perspectives-Working towards Coherence or Irreconcilable Diversity?," in The Oxford Handbook of Comparative Institutional Analysis, ed. John L. Campbell, Colin Crouch, Glenn Morgan, Ove Kaj Pedersen, and Richard Whitley, 16-40. Oxford: Oxford University Press.

Doppelt, G. 1981. "Rawls' System of Justice: A Critique from the Left," Noûs 15(3): 259307. http://dx.doi.org/10.2307/2215434

Edward, P., and H. Willmott. 2008. "Corporate Citizenship: Rise or Demise of a Myth?," Academy of Management Review 33(3): 771-73. http://dx.doi.org/10.5465/AMR.2008.32465773

Esping-Andersen, G. 1990. The Three Worlds of Welfare Capitalism. Cambridge: Polity Press.

1996a. "After the Golden Age? Welfare State Dilemmas in a Global Economy," in Welfare States in Transition: National Adaptations in Global Economies, ed. G. Esping-Andersen, 1-31. London: Sage.

, ed. 1996b. Welfare States in Transition: National Adaptations in Global Economies. London: Sage.

1996c. "Welfare States without Work: The Impasse of Labour Shedding and Familialism in Continental European Policy," in Welfare States in Transition: $\mathrm{Na}$ tional Adaptations in Global Economies, ed. G. Esping-Andersen, 66-87. London: Sage.

Eyal, N. 2005. "Perhaps the Most Important Primary Good: Self-Respect and Rawls's Principles of Justice," Politics, Philosophy, and Economics 4(2): 195-219. http://dx.doi.org/10.1177/1470594X05052538

Fama, E., and M. Jensen. 1983. "Separation of Ownership and Control," Journal of Law and Economics 26(2): 301-25. http://dx.doi.org/10.1086/467037

Ferguson, I., M. Lavalette, and G. Mooney. 2002. Rethinking Welfare: A Critical Perspective. London: Sage Publications.

Fleurbaey, M. 2006a. Capitalisme ou démocratie? L'alternative du XXIème siècle. Paris: Grasset.

2006b. "Mesurer les inégalités et dire l'injustice," in L'Etat des intégalités, ed. L. Maurin and P. Savidan. Paris: Belin.

Freeman, S. 2007. Rawls. Milton Park: Routledge.

Guillarme, B. 1999. Rawls et l'égalité démocratique. Paris: PUF. 
Gutmann, A., ed. 1988. Democracy and the Welfare State. Princeton, N.J.: Princeton University Press.

Habermas, J. 2005. Une époque de transitions: écrits politiques, 1998-2003, trans. C. Bouchindhomme. Paris: Fayard.

Heath, J., J. Moriarty, and W. Norman. 2010. "Business Ethics and (or as) Political Philosophy," Business Ethics Quarterly 20(3): 427-52.

http://dx.doi.org/10.5840/beq201020329

Hsieh, N. 2004. "The Obligations of Transnational Corporations: Rawlsian Justice and the Duty of Assistance," Business Ethics Quarterly 14: 643-61. http://dx.doi.org/10.5840/beq200414437

2005. "Rawlsian Justice and Workplace Republicanism," Social Theory and Practice 31(1): 115-42. http://dx.doi.org/10.5840/soctheorpract20053116

2008a. "Survey Article: Justice in Production," The Journal of Political Philosophy 16: 72-100. http://dx.doi.org/10.1111/j.1467-9760.2007.00290.x

2008b. "Workplace Democracy, Workplace Republicanism and Economic Democracy," Revue de Philosophie Economique 9(1): 57-78.

Hussain, W. 2009. "The Most Stable Just Regime," Journal of Social Philosophy 40(3): 412-33. http://dx.doi.org/10.1111/j.1467-9833.2009.01460.x

2012. "Nurturing the Sense of Justice: The Rawlsian Argument for Democratic Corporatism," in Property-Owning Democracy: Rawls and Beyond, ed. M. O'Neill and T. Williamson, 180-200. Malden, Mass.: Wiley-Blackwell.

Machan, T. R., and J. Chesher. 2002. A Primer on Business Ethics. Lanham, Md.: Rowman \& Littlefield.

Maitland, I. 2001. "Distributive Justice in Firms: Do the Rules of Corporate Governance Matter?," Business Ethics Quarterly 11(1): 129-43. http://dx.doi.org/10.2307/3857873

Massey, S. J. 1983. "Is Self-Respect a Moral or a Psychological Concept?," Ethics 93(2): 246-61. http://dx.doi.org/10.1086/292432

McCall, J. J. 2001. "Employee Voice in Corporate Governance: A Defense of Strong Participation Rights," Business Ethics Quarterly 11(1): 195-213. http://dx.doi.org/10.2307/3857877

McGregor, D. 1960. The Human Side of Enterprise. New York: McGraw-Hill.

Mitchell, T. R. 1973. "Motivation and Participation: An Integration," Academy of Management Journal 16(4): 670-79. http://dx.doi.org/10.2307/254699

Moriarty, J. 2005. "On the Relevance of Political Philosophy to Business Ethics," Business Ethics Quarterly 15(3): 455-73. http://dx.doi.org/10.5840/beq200515330

. 2009. "Rawls, Self-Respect, and the Opportunity for Meaningful Work," Social Theory and Practice 35(3): 441-59.

http://dx.doi.org/10.5840/soctheorpract200935325

Myles, J. 1996. "When Markets Fail: Social Welfare in Canada and the United States," in Welfare States in Transition: National Adaptations in Global Economies, ed. G. Esping-Andersen, 32-65. London: Sage.

Okin, S. M. 1989. Justice, Gender, and the Family. New York: Basic Books. 
O’Neill, M. 2008. "Three Rawlsian Routes towards Economic Democracy," Revue de Philosophie économique 9(1): 29-55.

. 2009. "Entreprises et conventionnalisme: régulation, impôt et justice sociale," Raison publique 10: 171-200.

Phillips, R. A., and J. D. Margolis. 1999. "Toward an Ethics of Organizations," Business Ethics Quarterly 9(4): 619-38. http://dx.doi.org/10.2307/3857939

Rawls, J. 1971. A Theory of Justice. Cambridge, Mass.: Belknap Press of Harvard University Press.

1993. Political Liberalism. New York: Columbia University Press.

1999a. Collected Papers, ed. S. R. Freeman. Cambridge, Mass.: Harvard University Press.

1999b. A Theory of Justice, rev. ed. Cambridge, Mass.: The Belknap Press of Harvard University Press.

. 2001. Justice as Fairness, a Restatement. Cambridge, Mass.: The Belknap Press of Harvard University Press.

2005. Political Liberalism, expanded edition. New York: Columbia University Press.

Rosanvallon, P. 1981. La crise de l'Etat-providence. Paris: Seuil.

Schwartz, A. 1982. "Meaningful Work," Ethics 92(4): 634-46.

http://dx.doi.org/10.1086/292380

Shue, H. 1975. “Liberty and Self-Respect," Ethics 85(3): 195-203. http://dx.doi.org/10.1086/291957

Stedman Jones, G. 2005. An End to Poverty? A Historical Debate. New York: Columbia University Press.

Stephens, J. S. 1996. "The Scandinavian Welfare States: Achievement, Crisis and Prospects," in Welfare States in Transition: National Adaptations in Global Economies, ed. G. Esping-Andersen, 32-65. London: Sage.

Taylor, R. S. 2004. "Self-Realization and the Priority of Fair Equality of Opportunity," Journal of Moral Philosophy 1(3): 333-47. http://dx.doi.org/10.1177/174046810400100307

Van Parijs, P. 1995. Real Freedom for All: What (if Anything) Can Justify Capitalism? Oxford: Clarendon Press.

. 2003. "Difference Principle," in The Cambridge Companion to Rawls, ed. S. Freeman, 200-40. Cambridge: Cambridge University Press.

Walzer, M. 1988. "Socializing the Welfare State," in Democracy and the Welfare State, ed. A. Gutmann, 13-26. Princeton, N.J.: Princeton University Press.

Williamson, O. E. 1975. Markets and Hierarchies. New York: Free Press.

Witztum, A. 2008. “Corporate Rules, Distributive Justice, and Efficiency,” Business Ethics Quarterly 18(1): 85-116. http://dx.doi.org/10.5840/beq20081818 